\title{
Public Administration in Afghanistan: Challenges and Way Forward
}

\author{
Shaheen Yusufzada, Zhiqiang Xia \\ School of Public Administration, Sichuan University, Chengdu, China \\ Email: Shaheen_yousufzada@hotmail.com
}

How to cite this paper: Yusufzada, S. and Xia, Z.Q. (2019) Public Administration in Afghanistan: Challenges and Way Forward. Open Journal of Social Sciences, 7, 142-160. https://doi.org/10.4236/jss.2019.76012

Received: May13, 2019

Accepted: June 17, 2019

Published: June 20, 2019

Copyright $\odot 2019$ by author(s) and Scientific Research Publishing Inc. This work is licensed under the Creative Commons Attribution International License (CC BY 4.0).

http://creativecommons.org/licenses/by/4.0/

\begin{abstract}
Public administration is the key instrument of government for ensuring public interests. This article seeks to explore the status of public administration in Afghanistan as well as challenges faced and way forward to sustainable development. A qualitative approach has been employed particularly desk review. A number of secondary sources have been consulted to substantiate the argument. This study reveals that the status of public administration in Afghanistan is very poor, suffering from lack of strong structural body, efficient public administrators, and bureaucracy. The public administration in Afghanistan is still facing major challenges such as corruption, lack of professionalism, absence of rule and law, lack of institutional strategic planning, politicization, and ethnical discrimination. All public agencies are also characterized by lack of transparency, nepotism and concentration of power in even in the judicial system. This article suggests that Afghan government needs a professional team with the strong political leadership with commitment to fight against, administrative corruption, ethnical discrimination, non-transparency and inefficiency to strengthen effective administrative system, and sustainable development. The implementation of rule of law is the prerequisite to ensure good governance and sustainable development. The finding of this research will support the public administrators, researchers, scholars, political leaders and policymakers to make the perfect and practical policies and plans for a sustainable future development in Afghanistan.
\end{abstract}

\section{Keywords}

Public Administration, Bureaucracy, Sustainable Development, Good Governance, Afghanistan

\section{Introduction}

Afghanistan is a developing country with a population of nearly 32 million, low 
per capita income, and the economy is dominated by agriculture [1]. Afghanis$\tan$ is landlocked and shares borders with Pakistan, Iran, Turkmenistan, Uzbekistan, Tajikistan, and China with a population of around 30 million, it has an area of $647,500 \mathrm{~km}^{2}$ [2]. The administrative system in Afghanistan is Republic and concentrated central system. The cabinet is the highest collective decision-making body of the whole government under the office of the president of Afghanistan government [3]. The cabinet is composed by two vice presidents, chief executive, and two vices of chief executive, 25 cabinet ministers, 4 state ministers, 7 general directorates (including the mayor of Kabul) and 3 senior advisers. Each ministry is in charge of related ministries and they are the "political head" of that ministry [4]. One ministry consists of at least two divisions and several branches. The local government structure is composed of provinces, municipalities, and districts and villages. The highest administrative unit is the local government of the province. The whole country divided into 34 provinces, with a total of 399 administrative districts; all province's heads (governors) appointed by the president. In fact, the local government formation is a set of branches of the central government [5]. The authorities and responsibility of the local government are organized by the central government. Currently, due to lack of proper management and security issues, the living conditions, social welfare, security, and service delivery are not good [6].

In terms of security, Afghanistan lacks long-term security stability, which has reduced government authority in Afghan provinces and has challenged local public administrations. Based on recent research, the authority of the Afghan government is restricted in many parts of Afghanistan, and the Taliban and other terrorist groups turned in to real treatments against to the public administration and the good governance in Afghanistan [7].

According to reports, currently 122 districts (30\% of the territory) of Afghanistan are completely under control of the Afghan government. The Taliban controls 14 districts (4\% territory) of Afghanistan, and the other 253 districts (66\% of the Territory) [8]. Although under the control of the Afghan government, but sometime Taliban and various terrorist groups and illegal armed groups carry out terrorist activities in these districts; it is around 15 million Afghan populations that live in these areas. Thus, instability in these areas of Afghanistan is considered as a major obstacle to the delivery of government services and good governance [9]. The main objective of this paper is to explore the current situation of public administration and analyze the main problems and challenges influencing good governance in Afghanistan. This article also proposes some specific suggestions and countermeasures for improving the administrative system of Afghanistan.

\section{Literature Review}

Afghanistan is largely suffering from corruption with other challenges. Sadr [1] assessed people's attitudes towards corruption, reviewing the current situation, the effectiveness of efforts to eliminate administrative corruption, and finding 
ways to fight against corruption. He reveals that insecurity remains at the top of Afghanistan's biggest challenges with $34.42 \%$. Unemployment ranks second with $25.86 \%$, and corruption is ranked third with $23.98 \%$. They also reported that corruption in Afghanistan has become a threat to national security, which has threatened the life of the Afghan government. Following the phenomena of insecurity and unemployment, corruption is one of the major threats against Afghan national security.

Blunt et al. [3] assessed the main challenges of local governments in Afghanistan and found that there are still numerous challenges (i.e. corruption, illiteracy, poverty, unemployment, abuse of law, and lack of strategic planning, etc.), which are the comprehensive causes of inefficiencies in local administration and dissatisfaction with local government.

Guinn and Straussman [4] examined the state of good governance in Afghanistan through evaluating various indicators in details and indicate that the lack of good governance in Afghanistan is caused by failures in all four sectors like lack of rule of law, mismanagement of human resources, low administrative capacity and financial and administrative corruption. Accordingly, the problems in the four named sectors can be considered as serious challenges to good governance in Afghanistan.

Roberts [5] observed that administrative corruption is the biggest challenge for the government which also penetrated the administrative system extensively. Although in the past few years, the Afghan president has made many promises at the international conference to completely eliminate corruption, so far, we have not seen any high-level government officials caught by the investigation. He also stressed that unless the issue is actively addressed, corruption cannot be eradicated.

Bizhan [8] analyzed the public administration of Afghan and concluded that the biggest mistake of the international community since 2001 was that the leadership of a part of the Afghan public administration was overthrown by the warlords and ignored the importance of the public administration, even though the Afghan-international community provided a lot of assistance to the Afghan government. The opportunities were lost and resources were looted due to non-professional and opportunist people who were responsible for various government offices. As a result, good governance has encountered with challenge and corruption.

\section{Methodology}

A qualitative approach has been employed particularly desk review. A number of secondary sources have been consulted to substantiate the argument. The research study is descriptive in nature. Research for this study mainly used first-hand materials, journal articles, books, newspapers, national and international academic articles, and reports to conduct qualitative analysis and substantiate the argument. 


\section{Results and Discussion}

\subsection{Present Status of Public Administration in Afghanistan}

After 9/11 the establishment of the new Afghan government. On January 2004 Afghanistan's Loya Jirga (Grand Council) formulated \& passed a new constitution, laying a political and legal foundation for the establishment and implementation of the country's current political and administration system. The Afghan Constitution presents features such as strong Executive Branch and the weak judicial branch, strong central government and weak local governments, reflecting the development trend of strengthening centralization rather than enhancing local decentralization. In the Afghan Constitution, Articles 71 to 80 about executive branch; Articles 81 to 109 about legislature branch, Articles 116 to 135 about judiciary branch, Articles 136 to 142 about central and local government discussed clearly. According to the constitution, the legal structure of Afghan administration consists of three branches: Executive branch, Legislature branch and Judiciary Branch [1].

In addition, there is also traditional grand council (Loya Jirga) convened the Jirga Grand Council while need makes decisions about some major national events, such as national sovereignty problems, amending the Constitution and the president's trial [10].

\subsection{Executive Branch}

President as head of state and chief of the executive branch holds the all power and authority in Afghanistan, not only leading the cabinet but also, he is the highest chief of the armed forces. The president elected by the people in general election by obtaining more than $50 \%$ of the votes for a term of five years. And has two first and second vice presidents. If the president is unable to perform his duties, the first vice president and the second vice president are appointed as the president to manage the administrative system [10]. The overall office of the president consists of the office of the president itself, the security council, the press office, and the office of administrative affairs. The cabinet is headed by the president and consists of two vice presidents, 25 ministers, and the other independent institution; According to constitution, the cabinet ministers, the chief judicial branch, chief and members of the high court, the Directorate of national security, chief of central bank and the chief of the Afghan red crescent society are appointed by the president and elected by the national parliament. Other position administrative positions, such as the vice president, the mayor, and the chief of the commissions, are appointed by the president no need the approval of the National Assembly. The Executive is organized on the basis of ministries and, within ministries, by divisions

\subsection{Legislative Branch}

National Assembly is often called parliament is the supreme organs of Afghan legislative power. The national assembly consists of the upper house (the house 
of the elders) and the lower house (the people's house); members of the lower house (Wolesi Jirga) selected through the public election vote for five years [11]; The Afghan lower house (Wolesi Jirga) currently has 249 members, 181 seats for men and 68 seats reserved for the women.

The members of the upper house (Meshrano Jirga) are selected by a mix of Presidential appointments and indirect elections. The Constitution states that the President shall appoint one-third of the members of the Meshrano Jirga (upper house) for a five-year year, including two representatives of the disabled and two representatives of the herdsman (Kuchi) population. The other members of the Upper house (Meshrano Jirga) are indirectly elected by the Provincial and District Councils. Each Provincial Council elects one representative for a four-year term. And the District Councils within each province select one representative for a three-year term. Fifty percent of the Presidential appointments must be women. There are currently 102 members of the Meshrano Jirga and 14 commissions. District Council elections have not been held. Accordingly, the Provincial Councils currently select two members to the Meshrano Jirga, one for a four-year term and one for a three-year term or until district elections are held.

\subsection{Judiciary Branch}

Constitution provides for the separation of powers with an independent judiciary, though up to now the administration of the lower judiciary has been in the hands of the ministry of justice. The Afghanistan judicial system comprises three judicial institutions: the supreme court, the courts of appeal, and primary courts. The supreme court is at the head of the judiciary as the highest judicial organ. The supreme court consists of nine members appointed by the President and elected by the parliament. According to 50 and 118 articles of the constitution, three members of the supreme court appointed for a term of four years, three members for a term of seven years and three for a term of 10 years. It has both judicial competencies related to the delivery of justice as the court of cassation as well as administrative competences resulting from its status as the highest administrative organ of the judiciary [1]. Article 31 of the law on courts enumerates the court's judicial responsibilities and Article 32 provides for the administrative duties. The supreme court is given the power to review laws, legislative decrees, international treaties, and conventions for their compliance with the constitution. The Court has the authority to interpret laws, legislative decrees, and the constitution, "upon the proposal of the government or courts.

\section{Major Challenges of Public Administration in Afghanistan}

After the establishment of the new government in Afghanistan on 2001, the International community continuously support Afghan government for continuing efforts to enhance the quality of governance in the country, but the development of Afghanistan is still suffering from numerous and different governance-related inefficiencies and complication including structural and non-structural prob- 
lems. The major challenge of good public administration in Afghanistan is: how can we provide the basic needs of the people with the fair and reasonable participation of all the people of the country?

\subsection{Institutional Problems}

\subsubsection{Centralized Administrative System}

Afghan government experts directly copy the western administration system for our government system, and this western system has not undergone domestic localization; that is why that cannot adapt or respond to higher efficiency. Therefore, it is necessary for Afghan experts to design an administrative system which responds the current situation of our country in order to ensure the good performance of public administration in Afghanistan.

\subsubsection{Corruption}

One of the biggest challenges which slow the development and good governance in Afghanistan is corruption [10]. Corruption is one of the main reasons for Afghanistan's backwardness. After 18 years, corruption not only this phenomenon has not been seriously eradicated but has also increased. Its roots have spread more widely within government sectors and institutions. The central government and local governments of Afghanistan are infected with very serious corruption, which is mainly reflected in several aspects: First, recruitment system infected by the corruption. The cadres central \& local government mostly selected based on Ethnic affiliations, Ethnic quotas or bribery rather than professional skills and Scientific Capacity. Second, the bribes are serious in the administration system. If anyone plane to handle any problem or solve the problem, he/she should pay the bribe. Otherwise, the problem can't be solved. These phenomena negatively affect the smooth implementation of the law, decrease the effectiveness of administration, and effects of justice, fairness, equality, and justice in the judicial sectors. Corruption became very common like the culture. According to the report of "Transparency International" from 2013 up to 2016, among 175 countries, Afghanistan introduced as one of five most corrupted countries in the world and in 2018, ranked $172^{\text {th }}$ at global ranking [12]. Although the government has made efforts to curb corruption and reform the environment under the pressure of international donors, the anti-corruption and enforcement agencies have been established to implement anti-corruption actions in 2008, but so far, there is no obvious result. In addition, the Afghan government has a series of anti-corruption commitments to the international community. Unless efforts are made to eradicate corruption at all, international donors will stop aid to Afghanistan.

\subsubsection{Lack of Defined Responsibility}

There are usually no precise definition responsibilities in government sectors. In part of its departments and small units, there is no balanced balance between the competencies and responsibilities of posts, and some posts are not in accordance with the specific requirements of the administration. In such a situation, due to 
the fact that the description of the duties of the employees is not precise and measured, the employees either become confused or do things that are not strictly their main occupational responsibilities [13]. Also, organizational inflation in some of the country's offices is another problem of efficiency and job performance. In such a situation, a job that can be done by an individual during an eight-hour administrative period is practically done by several people [14]. So, each person can only use part of the time properly.

\subsubsection{Lack of Capacity Building of Human Resource}

Most of the international institutions have considered the level of education, skills, and expertise of a nation as the main factor of development and prosperity, the quality and quantity of expertise and educated population are specified as an independent variable for development. Therefore, the Afghan government due to lack of effective, skilled and educated expertise capacity, not able to properly use the existing resources implement the government projects to achieve strategic goals. Recruitment system is mainly based on relation and nepotism rather than merit. Thus, these mechanisms will prevent skilled and qualified personals without relation with the political leaders to enter the administration system [15]. The commission of "administrative reforms" established through a presidential decree in order to enhance the capacity of human resources in Afghanistan's public sector and to improve the administrative management, has failed to conduct its duties. Even in appointing the commission's personnel, nepotism played its role and prevented the educated, skilled and consequently the right people to rule and manage the commission.

\subsubsection{Rapid Turnover}

There are two main reasons of employee turnover in Afghan Government; first, consideration of work needs due to lack of professional staff of different units, sometimes it requires the conversion of professional staff. This conversion not only will bring a negative impact on the original units. But also, it needs more time to adapt and understand the new position. Second, because of political reasons, Afghan leaders and administrators belong to different political factions and national tendencies. When leaders of different levels come to power, they try to find out some employees to be more trustable for then, thus, they bring some changes in employee turnover in their own positions [15]. But these Changes in Afghan government sectors actually have a political motivation, not in order to improve work and administrative requirements.

\subsubsection{Lack of Coordination}

The main function of the administration work is communication and coordination through communication and coordination, the links between various departments can be strengthened, the information channels between sectors can be smoothed [16] [17]. It is also necessary to ensure that the contradictions can be alleviated, the relationship can be rationalized, the disorder can be transformed into order, and agencies can concentrate on their planning [18]. The public ad- 
ministration departments in Afghanistan are relatively scattered, and there is a lack of systematic communication and coordination between units. Therefore, due to lack of coordination among the sectors in government, sometimes deference sector does the same and repeating work.

\subsubsection{Lack of Strategic Planning}

Facilitating and ensuring the maximization of the interests of the people are the main purpose of public administration [19]. The realization of the people's interests depends on the planning and strategies; but at currently, lack of strategic plans government structures is another major dilemma for good governance in Afghanistan [10]. Most government agencies suffer from the lack of long-term plans and targeted solutions. It is believed that returning to offices without work plans has become the culture of Afghan official offices. This approach has led the employees of government departments to never grow their capacity, and there is a bi-directional bureaucracy in the Afghan government departments, which has led to a reduction in the quality of the executive programs of the system. That is why that many projects cannot complete timely and in a proper way, and also cannot manage the resource of the country [20]. For example, the currency exchange rate in Afghanistan is unstable, rivers are disorder flow, frequent power outages, price instability, misuse of mining resources, and poor environmental protection. The relevant administration units of the government have not taken effective measures [21]. As a result, although a lot of manpower and material resources have been invested in public administration work, the effect of public administration work has not been improved, and the expected effect is not achieved [22].

\subsubsection{Lack of Participation of Women}

Women administrators are considered as good administrator due to sincerity in duty and performance better than men to empowering and encouraging employees, as well as in using managerial skills [17]. The Afghan women's participation in administration and public service units are very limited; Because of family, cultural, security and abuse issues by men and lack of a safe working environment. The media often reports the women's sexual harassment in the government's sectors. If the government has not provided a safe working environment, many families do not allow women to work in government sectors, and even many women voluntarily give up from working in the governmental sectors [23].

\subsubsection{Politicization}

Politicizing is responsible factor to destroy the administrative and economic system. Over the past decade, political leaders and politicians, in order to seize power and keep influence illegally hire their supporters in government administration system and change the administrative process in their favor Afghanistan [8]. For example, the interfering of government leaders in the election commission is as a typical example. Today it became a culture and the only solution to 
take political power, and achieve illegal economic and wealth benefits from the big economic projects. Now the most of sectors in Afghanistan expendable politicize and tend to different political parties, bonds, ethnic groups and etc., such as police stations, security forces, judicial organs, legislatures, and administrative agencies. The politicization of the internal institutions caused increasing the insufficiency of management, corruption, and political conflicts in the government.

\subsubsection{Lack of Adequate Supervision}

The lack of accurate and sustained monitoring between government agencies is one the serious problem in the government of Afghanistan. The governmental institutions are democratically accountable to the parliament and provincial councils, we rarely see that parliament and local provincial council to monitor the government institution behavior. And also, they're not timely and effective supervision between administrations levels of the management; the evaluation efficiency and assessing the performance is an important part of public administration which has been forgotten in Afghan management system [24]. Unfortunately, the lack of adequate oversight of the projects and national processes has caused to increase lack of transparency and misuse the human, financial, and natural resources.

\subsubsection{Lack of Rewards and Punishment Mechanisms}

Reward and punishment are two contradictory concepts and effective mechanisms in public administration but Afghanistan public administration suffers due to lack of clear mechanism for rewarding and punishment for the personnel [5]. Basically, in all institutions, there will always be some brilliant, hard-working and weak employees; this is the task of the administrator to understand the pros and cons of the employees and appreciate or criticize them, but in our government institutions, there is no difference between good and bad employees. In contrast, they receive the same salary and the same rewards. In the long term, if the administrator continues to conduct employees equally, it will affect the motivation of excellent employees.

\subsubsection{Conservation}

Innovation and generation of ideas are prerequisites for the development of public administration [17] [21] [25]. In Afghanistan, because the leaders have more political interference to the work of government agencies, the administrators have not fully exerted their advantages in job development in order to maintain their own positions. Instead, they have adopted a negative attitude or a compliant attitude. Therefore, the conservatism of most government agencies has become a major obstacle to the development of departmental management [17] [22].

\subsection{Managerial Problems}

\subsubsection{Lack of Transparency}

Financial and administrative corruption is one of the most negative elements af- 
fecting good governance in Afghanistan the financial information and other national presses information not accessible to the public and the media [1]; if the Governmental Units extend the transparency of administrative procedures that people will be aware of the management procedure; but the work processes of our government sectors are complicated, unclear, slow, inefficient, untimely etc. Actually, the work that can be completed in one hour is postponed to one week or even months. This slow-moving procedure caused corruption. Meanwhile, the staff valuable time spend on doing redundant administrative work, and their main tasks cannot be completed [26].

\subsubsection{Lack of Familiarity with Information Technology}

Lack of familiarity with of information technology is another challenge and problem in the central and local government of Afghanistan, where government employees do not have access to modern facilities and equipment such as Internet, computers (e-government) and not familiar with the new technologies [10], and still use the hand processing system, and this problem cause that people spend a lot of time processing a very simple work.

\subsubsection{Non-Observe the Rule of Law}

Afghanistan has much more laws and regulations in different fields, and these beautiful rules have never been implemented. Principally any law and regulation are designed to standardize human behavior and bring the order in society [27]. In Afghanistan official never observe the law themselves, but they expect that the law to be observed by the common people. The government has not taken any appropriate and effective action against such a disorder of public social order, violating the law and rule change in a culture in Afghanistan.

\subsubsection{Abuse the Military's Vehicles}

The staffs are working in police stations or military camps often bring home police or soldier vehicles (tanks) and improper use in private works. It is often seen on the road that the police car is full of building materials, food, bricks, animals, etc.; in fact, those tanks should be used exclusively for police and security forces operations, should not use for any other private work; however, due to the government's mismanagement of these tanks, many opportunists use those tanks to transport drugs and dozens of other social illegalities and crimes under the name of the police.

\subsubsection{Abuse from the Security Forces}

In Afghanistan, when an official occupied a formal position in the government, the government will arrange security guards and transportation vehicles for him/her; however, when they leave the position, they do not reintroduce vehicles and security personnel back to the organs. It changes to a culture in Afghanistan. According to the latest government reports, some of the former official kept more than 5000 security forces and a large number of a vehicle after they left the official position [28]. 


\subsubsection{Political Intervention}

Political interference in the Afghan management system is very clear. Because the structure of the Afghan government is composed of political parties, interest groups, and ethical groups. And they have their own goals. In order to maintain and increase the influence of their own groups at different levels of the government, they widely intervene in government departments and public administration work [11]. The government leaders also intervene in the work processes of a number of independent commissions such as the Independent Election Commission, the Afghan Civil Service Reform Commission.

\subsubsection{Ethnic Discrimination}

Discrimination in Afghanistan is rooted in Afghanistan's history. In the past history, due to the rule of despotic systems, there have been various types of discrimination and injustice, and the people of Afghanistan have not enjoyed the equal rights, such as ethnic discrimination, religious discrimination, etc. Currently, the officials of the country belonging to different political parties and ethnic groups and they support their own nationalities, and interest group category [24]. Whether they are recruiting or promoting the staff the first criterion is such as ethnic groups, families. Even if they are unqualified in terms of conditions, they try the best to support them. Discrimination and injustice in Afghanistan are not limited solely to the issue of recruitment in government departments but includes all the networks of social and political relations. Such behavior violating the constitution and the laws Afghanistan and deprives professional administrators of the merits of recruitment and promotion. Increase the nationalization and non-professionalization of the department, at the resulting decline the fairness performance, and effectiveness of public administration in Afghanistan.

\subsubsection{Nepotism}

Nepotism means special favor to some special people. This is the most common problems in public administration of our country. This problem is common from the leadership level to the second and third levels of administration system; whether looking for a job or bidding on a project, every government official does his best to allocate public resources or job opportunities to his relatives and friends, even their relatives [13]. Friends are not educated and willing to settle down by various means. Such behavior seriously damages the values of reform, optimization, and social equity, fairness, equality, etc.; it is also the main reason why people are deprived of these opportunities and public resources.

\subsubsection{Centralized Power}

The distribution of power between high-level and low-level managers is a prerequisite for good governance, and it can ensure the efficiency and innovation of public management [29]. However, because Afghanistan lacks sufficient mutual trust between senior leaders, middle-level and low-level managers, power is not allocated to the following managers but is concentrated in the hands of individ- 
ual government leaders, thus the concentration power brought Bad effects in the administration system.

\subsubsection{Lack of Participation Public in Government Decision-Making}

The government takes authoritative measures and roles in any public issue of society. In the role of the government, it does not listen to citizens' opinions on social issues. The policy of the government cannot fully reflect people's needs; in addition, sometimes, although civil society demands the government, and government policymakers have no response to the people; this kind of behavior by the government has caused strong dissatisfaction among the citizens.

\subsection{Environmental Problems}

\subsubsection{Insecure Working Environment}

Secure environment is a prerequisite for the realization of good governance. If there is no security, strategic planning cannot be implemented. The security issue is a very big problem, especial for local government administration in Afghanistan. Although the Afghan government has planned a national development strategy to achieve the national goal of good governance, because of the security issues it is unable to implement good governance and timely supervision of the project. Peace and stability are closely related to good governance, just like triangles, interrelated and complementary. Without peace and stability, it is impossible to achieve the goal of good governance and sustainable development.

\subsubsection{Professional Inefficiency in Local Government}

Because of the security Issues the professional and skilled cadres only like to work in the capital the country or in the safe areas, and they are reluctant to join a team of local governments. This is why the local government suffering from an expert and faced with many problems and challenges in the management.

\subsection{Cultural and Educational Problems}

\subsubsection{Traditional Culture}

In the culture of Afghanistan, people grow up in a lazy habit, never pay much attention to time. People often say, "don't think about tomorrow, enjoy today"; in the eyes of Afghans, the good or bad of tomorrow depends on how God is doomed to you, and not depends on today's hardworking. The traditional idea is an obstacle to developing of public administration. Therefore, these traditional habits caused employees to spend most of their time on irrelevant and useless things, such as telling things they have experienced in the past.

\subsubsection{Traditional Education System}

The overall development of a country is directly related to the education system. Education has brought about tremendous changes in human behavior and ways of thinking. However, our Afghan education system is still a traditional system and cannot cultivate the talents that society needs. The reason why we cannot train such talents we need in our society is because our current education system 
has not been updated and modernized. The content is not suitable for cultivating talents with morality and patriotism. Primary education and higher education in Afghanistan focus on rote content and ignoring to bring up the way of thinking, creativity, and innovation. Textbooks and teaching supplementary are still a traditional mode, method, and goal, and have not been updated and professionally improved.

\section{Way of Achieving Effective Public Administration in Afghanistan}

\subsection{Security Stability Strengthening}

Security stability is a fundamental requirement for sustainable development in Afghanistan. There are many terrorist groups operating in Afghanistan, if the government not be able to control security stability challenges, and maintain the security stability throughout of the country, then we will never be able to realize the sustainable development, and it will be only a dream for Afghan people.

\subsection{Strengthen the Individual Role of Parliament Members}

Each member of our Parliament and provincial council represents from the group of people or parts of Afghanistan. The good and bad of these members depend on our choice in election day. In the past few years, some of the members of parliament are not entered to parliament through the voting of the people, in fact, they entered the parliament through fake votes, paying bribes and interfering of the government's leaders [4]. Therefore, it is very necessary for our people to actively and broadly participate in the parliamentary elections and choose the real representatives to create the functioning non-corruption parliamentary team to be accountable to the nation. And also, the independent election commission as the body organizer of the election should independently hold the election and grantee the transparency of election.

\subsection{Strengthening Parliamentary Oversight}

The constitution outlines that member of cabinet collectively and individually accountable to the parliament, for the strengthen parliamentary oversight, it is very necessary to be formed a capable parliamentary team, and the government provide logistical support and training programs to the parliamentary oversight committees and interior mechanism, and also need to establish joint oversight and government assurance committee to complete their oversight duties effectively [11].

\subsection{Political Stability in Parliamentary System}

Parliamentary political stability is also necessary for sustainable development in Afghanistan. At the current time, there are many ethical conflicts among the parliament members which disrupt the parliamentary political stability and sustainable development [30]. Political stability requires an effective parliamentary 
member to be away from any ethnic and political disputes and confliction.

\subsection{Localized Administration System}

The whole administration system and some policies using in Afghanistan have been copied from the western country are not compatible with the cultural, social, and historical condition of Afghanistan. It is required that Afghan specialists and scholars, took the experienced from the failure of the western model in Afghanistan, and by using the strengths of the western governance system, research and design a governance model which is compatible with the social, political, administrative and historical characteristics of Afghanistan [28].

\subsection{Creating Efficient Bureaucracy}

An efficient bureaucracy is a prerequisite for sustainable development; Afghanistan has an ineffective, inefficient bureaucratic system which had a negative impact on nationally sustainable developments. Both central and local governments lack the harmonious integrity and diversity of pluralism [1]. The government is required to employ patriotic experts who have no tendency to any ethnic groups, political groups which create an effective and different bureaucratic system can prevent the political interference of political parties, ethnic groups in the Afghan administrative system.

\subsection{Independent Judiciary}

The independent judiciary is necessary to ensure sustainable development. The country's judicial system should be independent and social justice should be available to all Afghan citizens. The Judiciary is the only Institution that can prevent illegal political leaders' involvement and intervention. The judicial system is also the guardian of the constitution and other basic rights of citizens of the country [5]. The independence of the judicial system for sustainable development and the rule of law in the country is a very significant issue.

\subsection{Rule of Law}

In public administration literature, the rule of law means all public duties to be done under the rule of law rather than the rule of man [10]. The rule of law is one of the essential conditions for the establishment of a good administration in the country, the government must maintain social order to establish good governance and sustainable development. Laws and regulations are considered as a good tool for maintaining order in a society. One of the main reasons for the disruption of the government in our country is the violation of the constitution and other laws by the deferent of the level of the administration. It is very necessary that seriously rule the constitution and other laws of the country; if anyone who violates the law must be punished.

\subsection{Eradication of Corruption}

Corruption is a major obstacle to the implementation of Afghanistan's strategic 
plans. Corruption has spread to all government departments in general and is almost the biggest hidden threat in our country [31]. It can only be eradicated altogether with a permanent and long-term anti-corruption agenda; Afghanistan created an independent anti-corruption commission in 2008, but political leaders intervened in the work of the Independent Commission They do. If government officials do not interfere in the work of that commission, corruption can be relatively effective. At the moment, the Afghan government needs urgent action to combat corruption, otherwise, it will ruin the government. In order to eliminate corruption, it is necessary to create a joint commission between government departments with the strong support of government leaders and to work hard to eradicate corruption.

\subsection{Capacity Building}

The capacity building certainly refers to strengthening the abilities, skills, and competencies of the personal that potentially achieve their goals in the work environment [26]. The Afghan government should launch a national capacity-building training program throughout of the country. In these programs, the cadres of administration and executives learn transparency, accountability, rule of law and democracy mechanisms in the administrative structures and then put these mechanisms in the action. Use the experience of countries of the world, this kind of training programs will be very useful and efficient to the administration of the country.

\subsection{Decentralization of Power}

The constitution of Afghanistan supports the central government which the power and authority gathering in the hand of the president that caused the institution and sub-institutional of central and local governments have little authority to use budget [9]. Centralization of power made a dictator government in Afghanistan; it is very necessary to adjust the constitution and establish the people directly elect their local government to enhance the decentralization administrative system and remove channel-based corruption.

\subsection{Independent Election Commission}

In order to promote sustainable development and democratization, the government should strengthen national institutions and strengthen the people's trust in the democratic institution. Unfortunately, over the past two decades, Afghan political leaders did not allow the Independent Election Commission (IEC) to take independent decisions related to the presidential and parliamentary election, but the government leaders continuously interfered in the election process. The government leaders should select the commission members in a transparency method and don't interfere on the work of the election commission. The commission should establish an electrical mechanism for collecting and calculating the votes in a clear and transparent mechanism and announce the result in a 
short time [6].

\subsection{Women Empowerment}

The Afghan Constitution emphasizes women's equality, prohibits any kind of gender discrimination, and ensures the extension of the opportunities in all area of civil life. These rules must be implemented. Experience has shown that women act more patiently and better in the management than men to empower and encourage employees as well as to use managerial skills [32]. Thus, the government of Afghanistan should ensure the safe environment and participation of the women in the administration levels.

\subsection{Citizen Access to Information}

One of the most useful ways of fighting against corruption is the public's access to public information. The Afghan Constitution outlines that all Afghan citizens have the right to access information from government departments within the bounds of the law; there are useful experiences of the international community, which shows: citizen access to information on human and financial resources will bring order and raises the administrative system transparency by monitoring of citizens from the government behavior [33] [34]. The Afghan government should make and pass the citizens' access information law, to ensure access to information.

\subsection{Implementation of E-Governance}

E-Government is an important tool for sustainable development. It applies a comprehensive and modern information technology to provide a new management system. The people can enjoy the service through a counter in 24 hours a day, without waiting in line and wasting of time [35] [36]. E-government can decentralize power, improve efficiency, enhance government transparency, improve the implementation of public policies, extend public participation in decision-making and establish good relations between government and public by improving the quality of public service.

\section{Conclusion}

Effective public administration is a prerequisite for the sustainable development of Afghanistan. The study was aimed to explore the status of public administration of Afghanistan and challenges and possible solutions. This study used a quantitative approach particularly desk review and used secondary materials extensively to substitute the argument. This study reveals that public administration of Afghanistan is suffering from its identity crisis, the lack of strong structure and poor bureaucracy. It is also found that public administration of Afghanistan is still facing many challenges such as corruption, the lack of professionalism, absence of rule and law, the lack of institutional strategic planning, abuse of public resources, serious politicization, ethnical discrimination, the lack of 
transparency, and the lack of security stability, nepotism and concentration of power. In order to create a good public administration system, it is necessary to take some important strategic steps to ensure sustainable and efficient administration in the country, such as eradicating corruption, solution of insecurity stability, strengthening the oversight role of parliament, localizing administration system, establishment of efficient bureaucracy, stopping interrupting in judiciary system, implementation of rule of law, capacity building of human resource, decentralizing power, stopping interruption on the national commission, empowerment of women, creating access information system for the citizens, and implementation of electronic government.

\section{Conflicts of Interest}

The authors declare no conflicts of interest regarding the publication of this paper.

\section{References}

[1] Sadr, O. (2019) Political Settlement of the Afghanistan Conflict: Divergent Models. Afghan Institute for Strategic Studies Political. Kārte Parwān, Kabul, Afghanistan.

[2] Blunt, P., Mamundzay, F., Yama, N. and Afghan, H. (2015) Policy Paradigms, Subnational Governance and the State Sovereignty Gap in Afghanistan. Progress in Development Studies, 15, 270-285. https://doi.org/10.1177/1464993415578981

[3] United Nation (2006) Islamic Republic of Afghansitan Public Administration: Country Profile. Department of Economic and Social Affairs (DESA), United Nations.

[4] Guinn, D.E. and Straussman, J.D. (2016) Improving the Budget Process in Fragile and Conflict-Ridden States: Two Modest Lessons from Afghanistan. Public Administration Review, 76, 263-272.

[5] Roberts, N. (2015) Coping with Wicked Problems: The Case of Afghanistan. In: Jones, L., Guthrie, J. and Steane, P., Ed., Learning From International Public Management Reform, Emerald Group Publishing Limited, Bingley, West Yorkshire, 353-375. https://doi.org/10.1016/S0732-1317(01)11006-7

[6] World Bank (2013) Afghanistan: Building an Effective State, Priorities for Public Administration Reform (Vol. 84). http://ir.obihiro.ac.jp/dspace/handle/10322/3933

[7] UNHCR (2005) Afghanistan: UNHCR Global Appeal 2005. Kabul, Afghanistan.

[8] Bizhan, N. (2018) Building Legitimacy and State Capacity in Protracted Fragility: The Case of Afghanistan. https://doi.org/10.2139/ssrn.3166985

[9] Hashimi, S.H. and Lauth, G. (2016) Civil Service Reform in Afghanistan: Roles and Functions of the Civil Service Sector. Afghanistan Research and Evaluation Unit, Afghanistan.

[10] Bahman, S.N. (2013) Good Governance in Afghanistan: Challenges and Solutions. http://www.nispa.org/files/conferences/2013/papers/201304161057480.Paper_Bach mann.pdf

[11] Lister, S. (2006) Moving Forward? Assessing Public Administration Reform in Afghanistan. Afghanistan Research and Evaluation Unit, Afghanistan.

[12] Transparency International (2019) Afghanistan Corruption Rank. https://tradingeconomics.com/afghanistan/corruption-rank 
[13] Sarker, N.I., Bingxin, Y., Sultana, A. and Prodhan, A.S. (2017) Problems and Challenges of Public Administration in Bangladesh: Pathway to Sustainable Development. International Journal of Public Administration and Policy Research, 3, 16-25.

[14] Sarker, N.I., Chanthamith, B., Anusara, J., Huda, N., Amin, A., Liu, J. and Nasrin, M. (2018) Determination of Interdisciplinary Relationship among Political Science, Social Sciences and Public Administration: Perspective of Theory and Practice. Discovery, 54, 353-359.

[15] Sultana, A., Sarker, N.I. and Prodhan, A.S. (2017) Job Satisfaction of Public and Private Primary School Teachers of Bogra District in Bangladesh. Journal of Sociology and Anthropology, 1, 41-46.

[16] Sarker, N.I., Wu, M., Shouse, R.C. and Ma, C. (2019) Administrative Resilience and Adaptive Capacity of Administrative System: A Critical Conceptual Review. ICMSEM-2019, 1-15.

[17] Sarker, N.I. (2019) Public Administration as an Academic Discipline and Social Science. In: Farazmand, A., Ed., Global Encyclopedia of Public Administration, Public Policy, and Governance, Springer, Cham, 1-8. https://doi.org/10.1007/978-3-319-31816-5 3856-1

[18] Sarker, N.I., Wu, M., Liu, R. and Ma, C. (2019) Challenges and Opportunities for Information Resource Management for e-Governance in Bangladesh. In: Xu, J., Cooke, F., Gen, M. and Ahmed, S., Eds., Proceedings of the Twelfth International Conference on Management Science and Engineering Management: Lecture Notes on Multidisciplinary Industrial Engineering, Springer, Cham, 675-688. https://doi.org/10.1007/978-3-319-93351-1 53

[19] Sarker, N.I., Wu, M. and Hossin, A. (2018) Smart Governance through Bigdata: Digital Transformation of Public Agencies. 2018 International Conference on Artificial Intelligence and Big Data (ICAIBD), Chengdu, 26-28 May 2018, 62-70. https://doi.org/10.1109/ICAIBD.2018.8396168

[20] Sarker, N.I., Hossin, A., Wu, M., Alam, G.M., Shafi, M., Pervez, A.K. and Rahman, A. (2018) Determinants and Pattern of Urbanization and Counter-Urbanization: The Case of South Asia. The Journal of Social Sciences Research, 4, 802-812.

[21] Sarker, N.I. (2019) Public Administration as a Professional Practice. In: Farazmand, A., Ed., Global Encyclopedia of Public Administration, Public Policy, and Governance, Springer, Cham, 1-6. https://doi.org/10.1007/978-3-319-31816-5 3853-1

[22] Sarker, N.I. (2019) Instrumentally Rationalizing Public Administration. In: Farazmand, A., Ed., Global Encyclopedia of Public Administration, Public Policy, and Governance, Springer, Cham, 1-5. https://doi.org/10.1007/978-3-319-31816-5 3861-1

[23] Sarker, N.I. (2016) Poverty of Island Char Dwellers in Bangladesh. Diplomica Publishing, Hamburg, Germany.

[24] DANIDA (2012) Evaluation of Danish Development Support to Afghanistan. Evaluation Department, Ministry of Foreign Affairs of Denmark, Denmark.

[25] Sarker, N.I. (2019) Administrative Resilience: Potential Approach for Disaster Management. In: Farazmand, A., Ed., Global Encyclopedia of Public Administration, Public Policy, and Governance, Springer, Cham, 1-5. https://doi.org/10.1007/978-3-319-31816-5 3868-1

[26] World Bank (2008) Afghanistan-Building an Effective State: Priorities for Public Administration Reform. Washington DC, 115.

[27] Sarker, N.I., Hossin, A., Min, W. and Aktaruzzaman, M. (2018) Poverty Alleviation 
of Rural People through Good Governance in Bangladesh. The Journal of Social Sciences Research, 4, 547-555. https://doi.org/10.32861/jssr.412.547.555

[28] Nijat, A., Gosztonyi, K., Feda, B. and Koehler, J. (2016) Subnational Governance in Afghanistan. Afghanistan Research and Evaluation Unit, Deutsche Gesellschaft für Internationale Zusammenarbeit (GIZ).

[29] Sarker, N.I. and Jie, Z. (2017) Social Security for Vulnerable Groups in Bangladesh on Government Perspective: Contribution of Research Leader. Journal of Public Policy and Administration, 1, 1-9.

[30] GIZ (2014) Strengthening Training in Public Administration. GIZ Country Office, Kabul, Afghanistan.

[31] SIGAR (2018) Afghanistan's Anti-Corruption Efforts: The Afghan Government Has Begun to Implement an Anti-Corruption Strategy, but Significant Problems Must Be Addressed.

[32] Sarker, N.I. and Sultana, A. (2017) An Investigation into the Status of Riverbank (Char) Women Dwellers in Bangladesh. International Journal of Rural Development, Environment and Health Research, 1, 86-92.

[33] Sarker, N.I., Hossin, A., Frimpong, A.N.K. and Xiaohua, Y. (2018) Promoting Information Resource Management for e-Government through Big Data Approach. In: Proceedings of the 2018 International Conference on Information Management \& Management Science, ACM, New York, 99-104. https://doi.org/10.1145/3277139.3277155

[34] Hossin, A., Sarker, N.I., Xiaohua, Y. and Frimpong, A.N.K. (2018) Development Dimensions of e-Commerce in Bangladesh. In: Proceedings of the 2018 International Conference on Information Management \& Management Science, ACM, New York, 42-47. https://doi.org/10.1145/3277139.3277152

[35] Cao, Q., Sarker, N.I. and Sun, J. (2019) Model of the Influencing Factors of the Withdrawal from Rural Homesteads in China: Application of Grounded Theory Method. Land Use Policy, 85, 285-289. https://doi.org/10.1016/j.landusepol.2019.04.013

[36] Sarker, N.I., Wu, M., Alam, G.M. and Shouse, R.C. (2019) Livelihood Vulnerability of Riverine-Island Dwellers in the Face of Natural Disasters in Bangladesh. Sustainability, 11, 1623. https://doi.org/10.3390/su11061623 